\title{
EGFR NM_005228.3:c.866C>T
}

National Cancer Institute

\section{Source}

National Cancer Institute. EGFR NM 005228.3:C.866C>T. NCI Thesaurus. Code C159426.

A nucleotide substitution at position 866 of the coding sequence of the EGFR gene where cytosine has been mutated to thymine. 